\title{
IMPLEMENTATION OF 3D CADASTRE WITH INDIGENOUS KNOWLEDGE CONCEPT OF "TRI HITA KARANA" IN BALI ISLAND, INDONESIA
}

\author{
Ketut Tomy Suhari ${ }^{1,2^{*}}$, Asep Yusuf Saptari ${ }^{1}$, Bambang Edhi Laksono ${ }^{1}$, Nyoman Robby Manik Saputra ${ }^{2}$, Putu Harry Gunawan ${ }^{3}$ \\ ${ }^{1}$ Bandung Institute of Technology, Dept. of Geodesy Engineering, Bandung, Indonesia - ketut.tomy.suhari@gmail.com \\ ${ }^{2}$ Kantor Jasa Surveyor Kadaster Berlisensi Ketut Tomy Suhari, Bali, Indonesia - kjskb.ketuttomysuhari@ gmail.com \\ ${ }^{3}$ Telkom University, School of Computing, Bandung West Java, Indonesia- phgunawan@ telkomuniversity.ac.id
}

KEY WORDS: 3D Cadastre, Indigenous Knowledge, Tri Hita Karana, Bali Island, BIM

\begin{abstract}
:
Sustainable development consists of the developing process of land, city, business, and community, which can be used for future generation. One of the tools for describing this process is called spatial planning. Spatial planning taking into account several aspects such as the number of plots (2D), vertical rooms or apartment (3D) of buildings and access to transport. The realization of this object requires the application of three-dimensional (3D) cadastre. This is essential for property rights to be registered and not superimposed. Traditionally, the cadastre is based on a representation of the $2 \mathrm{D}$ terrestrial division, but the $2 \mathrm{D}$ cadastre is not appropriate for applying and modelling information about the products. Some researchers have also discussed the options for transitioning 2D to 2D+ or three-dimensional (3D) registrations. According to Behnam et al (2016), the use of Building Information Model (BIM) as a feasible approach for managing land and property information in the administration of multi-storey buildings. Here, BIM is a technology capable of displaying the building's in 3D model which can provide any kind of information inside the building. In this research our focus on surveying and mapping the sustainable development of Balinese building structure based on their indigenous knowledge. From survey results, Bali has a unique building structure in land use terminology. Generally, Balinese people use the concept of Tri Hita Karana (relationship of God, Human and Environment) for building their home. Beside, in Bali, there is a local rule that the high of building has limitation of 15 meters or it should has 5 floors. Therefore, this will impact the development future infrastructures such as to build bridge, toll road, apartment, railway and etc. Thus the big challenge in this area is to sustain local culture but technology can be implemented.
\end{abstract}

\section{INTRODUCTION}

Sustainable development is a development process (land, city, business, community) based on the principle of meeting current needs without compromising the needs of future generations (Runa, 2012). Sometimes the increasing number of people is impacting on the land use needs, which are becoming more widespread and dynamic. Spatial planning taking into account several aspects such as the number of plots (2D), rooms or vertical flats (3D) and access to transport. This is necessary for the property rights to be registered and not overlapped. This could be done by the three-dimensional cadastre (3D) method.

Traditionally, cadastre is based on 2D land division representation (Stoter, 2004; van der Molen, 2003; van Oosterom et al., 2006), but 2D cadastre is not appropriate to apply and model commodity information and complex interests on land (Bennett et al., 2008; Kalantari et al., 2008). Some researchers have also discussed the options for transitioning 2D to 2D+ or three-dimensional (3D) registrations (Guo et al., 2012; Hespanha et al., 2006; Ho and Rajabifard, 2012; Stoter, 2004; van Oosterom et al., 2002). According to Behnam et al (2016), the use of BIM is a feasible approach for managing land and property information in the administration of multi-storey buildings.

BIM is a technology capable of displaying the building's 3D model with the information it contains (Mordue, Swaddle, \& Philip, 2016). Benham et al (2016) proposed to expand the use of the BIM standard to show ownership rights in 3D models. However, with 3D cadastral surveying, mapping and modelling using Building Information Model (BIM) can be implemented in the sustainable development in Bali? Or and how can its implemented of BIM for contradiction of indigenous in Bali?

Bali is one of the most well known in spiritual, cultural, linguistic and tourism provinces in Indonesia and is often called the island of the gods because of the padmasana (temple) which are seen in every corner of the house. The continued development of Bali should consider not the sustainability of natural resources as a fundamental need for life, but also the viability and sustainability of its cultural diversity (values, legends, ceremonies and old buildings). However, taking into account cultural sustainability does not exclude the possibility of its evolution from time to time because culture is lived.

Balinese have their own wisdom to manage the environment or develop land globally, thank to the concept of Tri Hita Karana, which, as indigenous knowledge, governs human relations with parayangan (God), between pawongan (humans) and humans with palemahan (their environment) (Bapedalda, 2012). Kaler (1982) stated that the concept of Tri Hita Karana, is profound, has tree layers / elements that are the soul, the energy and the physical. Then, in bhuana alit (humans), these three elements are atma, prana, and sarira, while in the bhuana agung (universe) are paramatma (God), prana (natural energy), and panca mahabhuta (earth, water, fire/light, air, ether). In the village, these three elements are bhatara (his unseen substance), karma desa (community members), and karang desa (the area of the village including residential areas, temples, and graves).

In the article 95 in paragraph b in Bali's regional regulation rules number 16 of 2009 concerning the spatial plan of the province of Bali, it states that the height of buildings utilizing air space above the earth's surface is limited to a maximum of fifteen (15) meters. Non-commercial buildings should exceed 
15 meters such as temples and public facilities. This is a government effort for get well managed the land use due to the fact that Bali is the relatively narrow and limited. Besides the government, this is the aspiration of the Balinese indigenous people who are very concerned about the spatial structure and culture.

Currently, many modern facilities (infrastructures) are being developed in Bali, including the Denpasar and Badung areas, such as tolls, airport, underpasses, shortened roads, tourist attractions and hotels. This, always applying Tri Hita Karana, is specifically aimed to attract tourism, facilitate the network access in order to eliminate and / or minimize the congestion and for sustainable development. So that $3 \mathrm{D}$ cadastral mapping using BIM is crucial and indispensable due to the fact that it can model the development that has now been completed and can be visualized for the interests of Bali in the tourism business and the infrastructures construction in the future.

\section{LITERATURE REVIEW}

\subsection{Traditional Balinese architecture according to} indigenous knowledge

Traditional Balinese architecture is among the most complex houses consisting of several buildings, surrounded by walls called penyengker walls. The dwelling is collection of several houses within a regional unit called banjar adat or desa adat and also a religious unit consisting of three temples of kayangan, namely; pura desa, pura puseh, and pura dalem. The realization of this form of house is inseparable from the rationale that is based on the order of people life that comes from Hinduism. In the philosophy of Hinduism, humans and universe are formed by the same five elements called "Panca Maha Bhuta"

Humans as micro-cosmos and nature as macro-cosmos that can not be separated. They are born of this nature and always depend on nature. The Bhuana Alit and Agung elements are the same, but on a different scale. Bhuana agung as a container and bhuana alit as content (Kumurur and Damayani, 2009). The harmonious relationship between bhuana agung and bhuana alit, providing the symbol of the manik ring сесирu (fetus in the womb) is an absolute thing and must be maintained for calm and stability of nature. The results of harmonious relationship between the container and the soul, will generate power. The combination of physical, mental, and energy elements is a good and perfect source of life called "Tri Hita Karana" (three elements of the source of goodness). The concept of Tri Hita Karana in the composition of the cosmos is shown in table 1.

\begin{tabular}{|c|c|c|c|}
\hline Elements & Atma & Prana & Angga \\
\hline $\begin{array}{l}\text { Universe } \\
\text { (Bhuana } \\
\text { Agung) }\end{array}$ & $\begin{array}{c}\text { Paramaatman } \\
\text { (God) }\end{array}$ & $\begin{array}{c}\text { Power to } \\
\text { control } \\
\text { nature }\end{array}$ & $\begin{array}{c}\text { The essence } \\
\text { of Panca } \\
\text { Mahabhuta }\end{array}$ \\
\hline Village & $\begin{array}{c}\text { Kahyangan } \\
\text { tiga } \text { (Village, } \\
\text { Puseh, and } \\
\text { Dalem Temple) } \\
\text { Pawongan } \\
\text { (Village } \\
\text { people) }\end{array}$ & $\begin{array}{c}\text { Palemahan } \\
\text { (Village } \\
\text { boundary } \\
\text { area) }\end{array}$ \\
\hline Banjar & $\begin{array}{c}\text { Pangan } \\
\text { (Banjar }\end{array}$ & $\begin{array}{c}\text { Pawongan } \\
\text { (Banjar }\end{array}$ & $\begin{array}{c}\text { Palemahan } \\
\text { (Banajar }\end{array}$ \\
\hline
\end{tabular}

\begin{tabular}{|c|c|c|c|}
\hline $\begin{array}{c}\text { In one } \\
\text { Building }\end{array}$ & $\begin{array}{c}\text { Temple) } \\
\text { Samerajan/ }\end{array}$ & Feople) & Area) \\
\hline $\begin{array}{c}\text { Humanan } \\
\text { (Bhuana } \\
\text { alit) }\end{array}$ & $\begin{array}{c}\text { Atman } \text { (human } \\
\text { soul) }\end{array}$ & $\begin{array}{c}\text { Sabarangan } \\
\text { rumah } \\
\text { (Boundary of } \\
\text { house) }\end{array}$ \\
\hline
\end{tabular}

Table 1. Concept of Tri Hita Karana (Budihardjo, 2013)

The basis of the concept comes from the ejection of Asta Kosala-Kosali and Asta Gumi. Parwata (2011) explains that the translation of the teachings of Tri Hita Karana and its relation to the concept of Tri Mandala is the relationship between human and God that was realized in the dimensions of the main space of the mandala (Utama Mandala). Human relations with each other are carried out in the dimensions of the Madya Mandala space. While the Nista Mandala dimension is the relationship between human and their environment. The concept of land used for Temple position in Bali can see in figure 1.

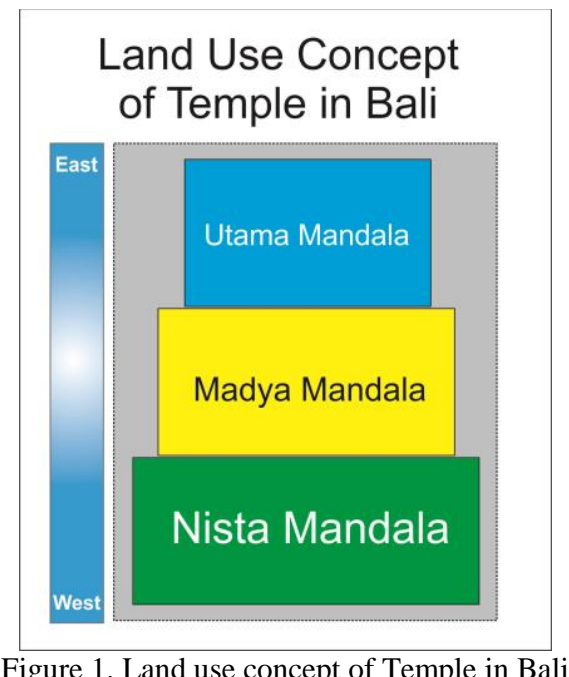

Soul and body driven by energy can be manifested in a place in relation to traditional villages:

- Kayangan tiga which are the soul of the village reef, and which is not separated from all village life.

- Krama desa is a villager or village apparatus, a driver or force that supports the village

- Karang desa is a territorial place where the people of village conducts activities to maintain the harmonious relations of the three elements above.

The harmonious relationship above can also be identified with the relationship between human and god (kayangan), human relations (karma desa), human relations with their environment (karang desa). This definition of Tri Hita Karana does not only apply for traditional villages, but it is also reflected in other bodies, for example in one traditional house unit which generally consist of sanggah, natah, and lebuh (can be seen in Figure 2.) 


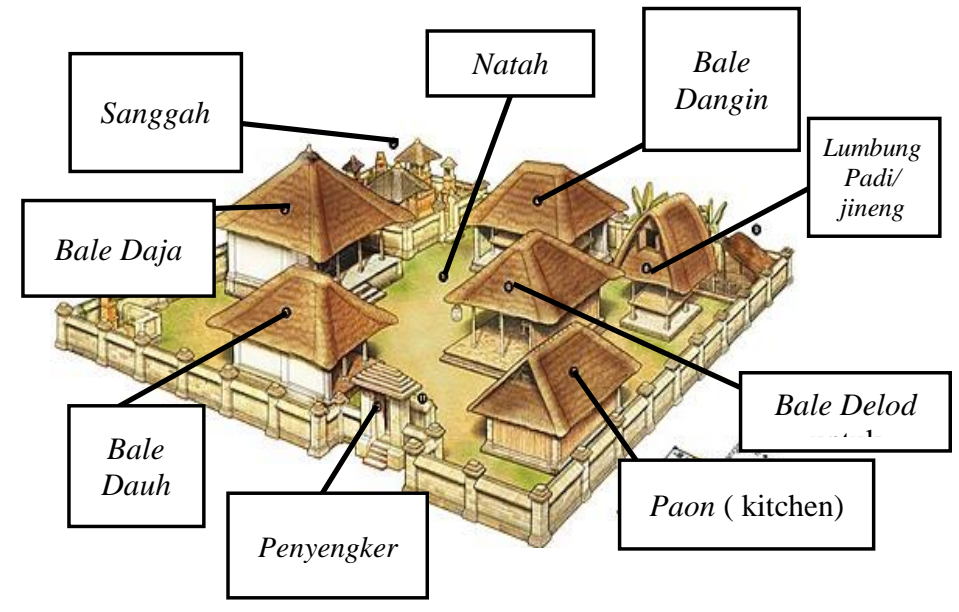

Figure 2. Illustration of traditional building in Bali.

- The area of refutation (sanggah atau merajan) is a prayer area to worship Sang Hyang Widhi, and the ancestors of each family.

- $\quad$ The land (natah) area or central courtyard is intended for the construction of a house where to sleep and for traditional ceremonies and for other social activities.

- Lebuh area is intended for arranging down unused materials and livestock land and agriculture.

\section{METHODOLOGY}

In this research the survey and mapping Balinese building concept is elaborated. Indeed for future research, this concept will be implemented in 3D cadastre technology where the local culture still be covered. The idea to deliver this concept to 3D cadastre technology is to use photogrammetry and BIM as shown in Figure 3.

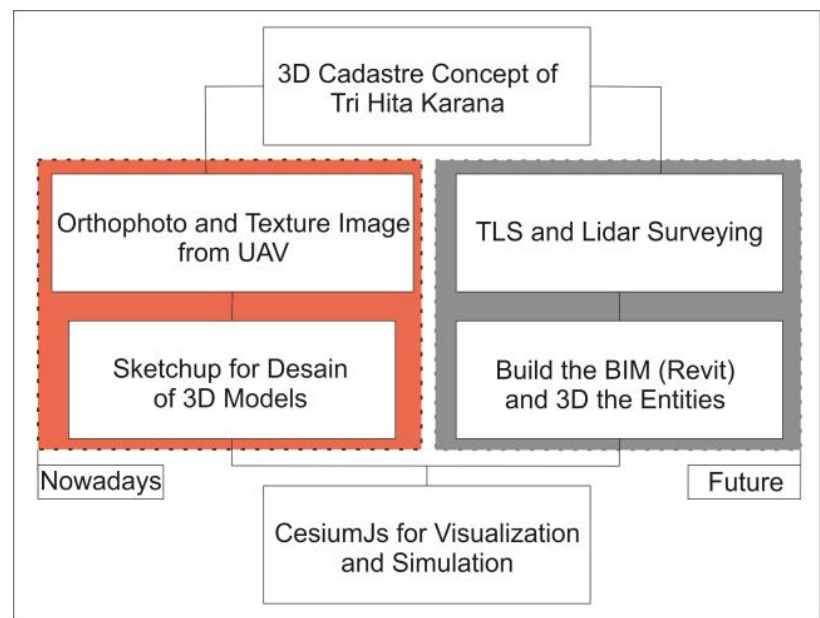

Figure 3. The methodology using Photogrammetry and BIM in 3D Cadastre.

In Figure 3, the methodology of this research is started from collecting data by photogrammetry using UAV or drone. Thus orthophoto and image texture can be extracted, visualized and modelled.

\section{DISCUSSION AND RESULT}

\subsection{Modern Balinese Buildings Concept and Infrastructure development according to Tri Hita Karana}

Traditional Balinese buildings will never go away, even if the technology continues to develop and this forces Bali to move towards modern sustainable development while keeping its traditions. Bali is full of customs and its culture will remain harmonious and sustainable even as technology and other developments continue to develop around the Tri Hita Karana.

According to Tri Hita Karana concept, the use of land in traditional house of Balinese can be seen in Figure 4. Figure 4 shows the specific location of buildings such that close to the Tri Hita Karana concept. Generally there are ten specific buildings based on Tri Hita karana concept, which are Sanggah, Bale Kaja, Bale Kangin, Bale Kelod, Bale Kauh, Lumbung, Paon, Padmasana, Natah, and Penyengker.

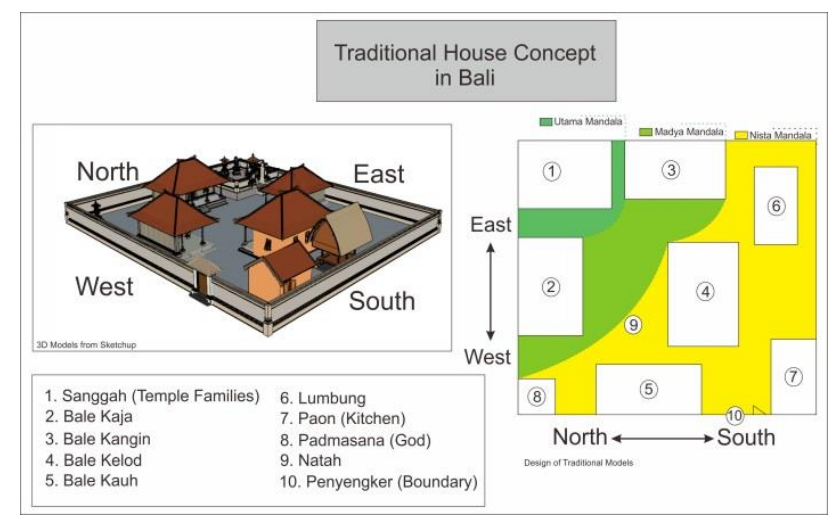

Figure 4. Traditional Building Concept

The existence of the implementation of Tri Hita Karana concept can be found in Figure 5. Here, the orthophoto sample is obtained from Siangan village which is located in Gianyar regency Bali. It can be seen clearly that there are three different families which have similar buildings concept (Tri Hita Karana) in their house. Moreover, the detail of building architecture can be seen in Figure 6.

Orthophoto in Siangan Village, Gianyar, Bali Land Use Concept of Tri Hita Karana

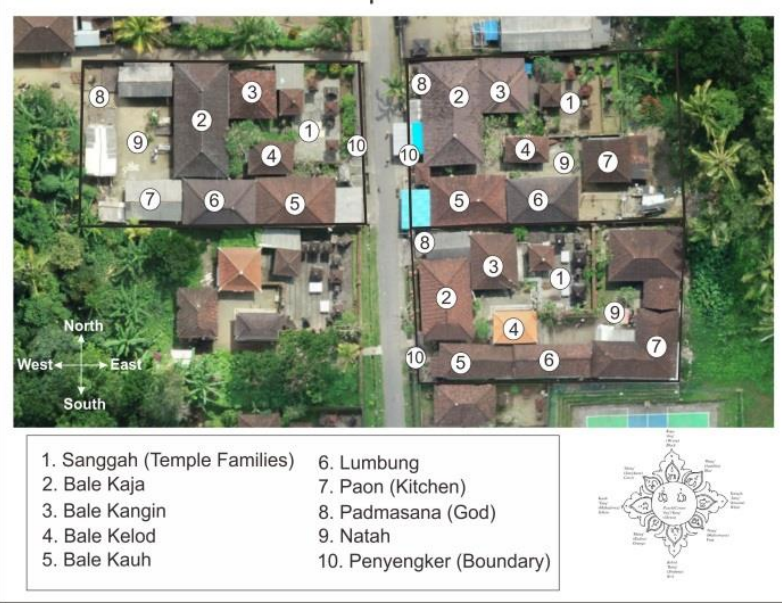

Figure 5. Result Orthophoto in Siangan Village 


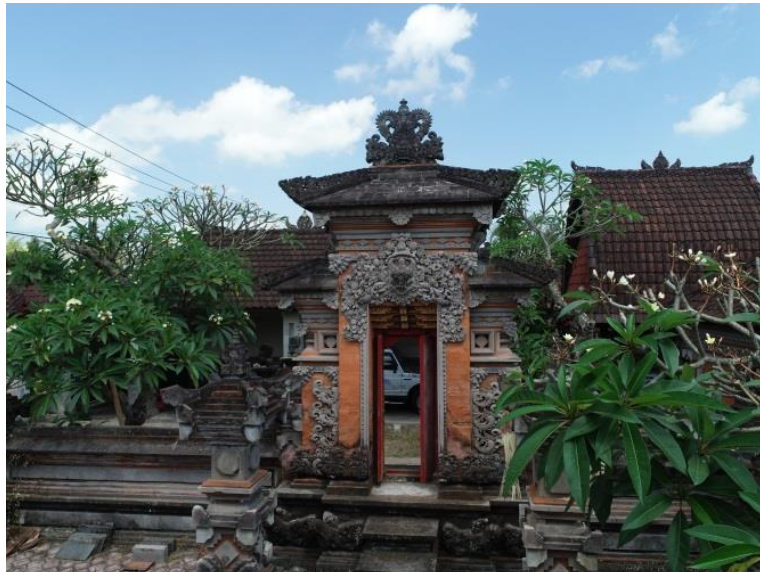

Figure 6. (left) Traditional gate of Balinese house. (right) Buildings architectures in Balinese house.

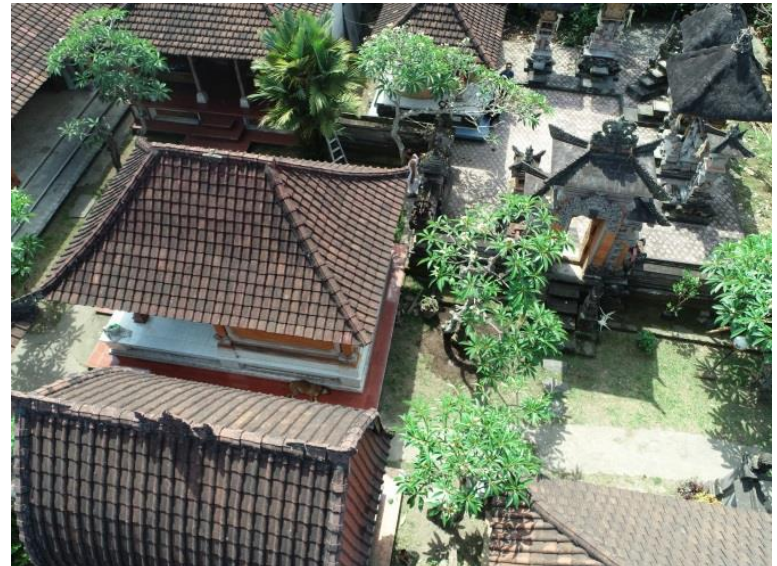

construction of the maritime highway has opened access to measurements and research on the marine cadastre and, on the other hand, to measurements involving the 3D cadastral system using a terrestrial laser scanner (TLS) and LiDar to monitor and visualize the construction of underground passageways from Denpasar to Nusa Dua (North to South) and it can be done as a prototype in interactive SmartCity.

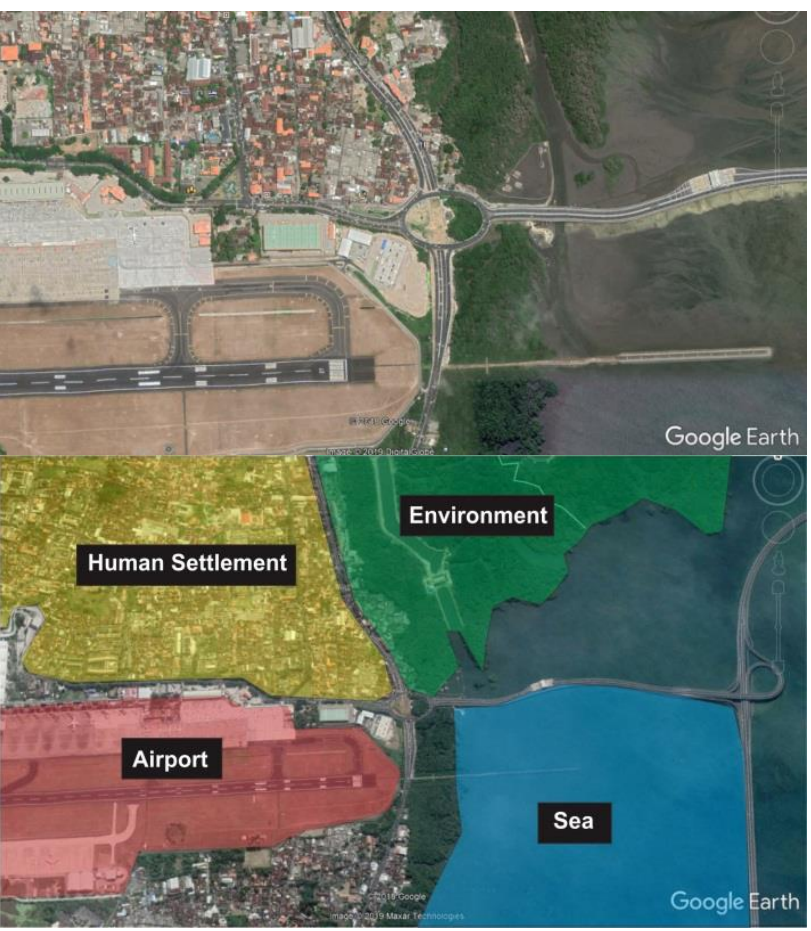

Figure 8. The presence of Tri Hita Karana concept in South of Bali area.

\section{CONCLUSION}

With technological advances and modernization of sustainable development, Bali will not eliminate Adat (traditional culture), its architecture and indigenous knowledge based on Tri Hita Karana. According to the law in Bali, the maximum building height is less than 15 meters or 4 to 5 floors. Buildings over 15 meters high only allow public facilities and temples to limit population and congestion. Generally there are ten specific buildings based on Tri Hita karana concept in Balinese house, which are Sanggah, Bale Kaja, Bale Kangin, Bale Kelod, Bale 
Kauh, Lumbung, Paon, Padmasana, Natah, and Panyengker. For modern house with small area of land, the concept of Tri Hita Karana still can be implemented with the only presence of Padmasana or Jero Gede holy statue.

For future work, trough this survey and mapping of Tri Hita Karana concept in Bali, the 3D cadastre can be implemented using BIM. BIM technology can change the land cadastral system from $2 \mathrm{D}$ to $3 \mathrm{D}$ and can be interactive in visualization with cloud databases. This BIM technology is expected to have place in the indigenous people of Bali, as it will facilitate knowledge of property information, visualization of Balinese architecture and should be used for tourism businesses.

\section{REFERENCES}

Aien, A., Kalantari, M., Rajabifard, A., Williamson, I., Wallace, J. (2013). Towards Integration of 3D Legal and Physical Objects in Cadastral Data Models. Land Use Policy, 35, p.140154.

Atazadeh, B., Kalantari, M., Rajabifard, A., Clark, J., Champion, T. (2016). Where BIM meets boundaries. Position Magazine, No. 82, April, p.28-31.

Atazadeh, B., Kalantari, M., Rajabifard, A., Ho, S. (2017a). Modelling Building Ownership Boundaries within BIM Environment: A Case Study in Victoria, Australia. Journal of Computers, Environment and Urban Systems, 61 (part A), p.2438 .

Atazadeh, B., Kalantari, M., Rajabifard, A., Ho, S., Champion, T. (2017b). Extending a BIMbased data model to support 3D digital management of complex ownership spaces. International Journal of Geographical Information Science, 31 (3), p.499-522.

Bapedalda Provinsi Bali dan Bali Travel News, 2012, Buku Panduan Tri Hita Karana, Yayasan Tri Hita Karana, Denpasar.

Kaler, I G.K., 1982, Butir-butir Tercecer Tentang Adat Bali 2, Bali Agung, Denpasar.

Budihardjo, R. (2013). Konsep Arsitektur Bali Aplikasinya pada Bangunan Puri. Jurnal Nalars Vol. 12 No. 01

Griffith-Charles, C., Sutherland, M., Davis, D. (2016). Capturing Legal and Physical Boundary Differences in 3D Space - A Case Study of Trinidad and Tobago. 5th International FIG 3D Cadastre Workshop, 18-20 October, Athens, Greece, p.433-446.

Guo, R., Ying, S., Li, L., Luo, R., van Oosterom, P. (2011). A Multi-jurisdiction Case Study of 3D Cadastre in Shenzhen, China: as Experiment using the LADM. 2nd International Workshop on 3D Cadastres. 16-18 November 2011, Delft, The Netherlands.

Hespanha, J. P., van Oosterom, P., Zavenbergen, J., Dias, G. P., 2006. A modular standard for the cadastral domain: application to the Portuguese Cadastre. Computers, Environment and Urban Systems, 30: 562-584.

Ho, S. and Rajabifard A., 2012. Delivering 3D Land and Property Management: A Consideration of Institutional
Challenges in an Australian Context, 3rd International Workshop on 3D Cadastres, 2012, Shenzhen, 219-242.

Kalantari, M., Rajabifard, A., Wallace, J., Williamson, I. (2008).Spatially referenced legal property object. Land Use Policy, 25, 173-181.

Kumurur, V.A; Damayanti, S. (2009). Pola Perumahan dan Pemukiman Desa Tenganan Bali. Jurnal Sabua Vol. 01 No. 01.

Mordue, S., Swaddle, P., Philip, D. (2016). Building Information Modeling For Dummies. Chicester: John Willey \& Sons, Ltd.

Parwata, I.W. (2011). Rumah Tinggal Tradisional Bali dari Aspek Budaya dan Antropometri. Jurnal Mudra Vo. 26 No. 01

Runa, W. I., 2012. Pembangunan Berkelanjutan Berdasarkan Konsep Tri Hita Karana Untuk Kegiatan Ekowisata. Jurnal Kajian Bali Vo. 02 No. 01.

Shojaei, D., Rajabifard, A., Kalantari, M., Bishop, I.D., Aien, A. (2014). Design and Development of a Web-Based 3D Cadastral Visualization Prototype. International Journal of Digital Earth, September, p.1-20.

Stoter, J.E., dan Ploeger, H.D. 2003. Property in 3D registration of multiple use of space: Current practice in Holland and the need for 3D cadastre. Computers, Environment and Urban Systems, 27: 395-410.

Stoter, J.E., dan zevenbergen, J.A. 2001. Changes in the definition of property: a consideration for a 3D Cadastral registration process. Proceedings FIG, Copenhagen.

Quintero, M. S., Genechten, B. V., Bruyne, M. D., Poelman, R., Hankar, M., Barnes, S., Taronger, J. M. (2008). Theory and practice on Terrestrial Laser Scanning. Europe: European Leonardo Da Vinci.

van der Molen, P., 2003. Institutional aspects of 3D cadastres, Computers, Environments and Urban Systems, 27: 383-394.

van Oosterom, P., Maessen, B., Quak, W., 2002. Generic query tool for spatiotemporal data. International Journal of Geographical Information Science, 16(8): 713-748.

van Oosterom, P., Ploeger, H., Stoter, J., Thompson, R., Lemmen, C., 2006. Aspects of a 4D Cadastre: a first exploration. Proceedings of XXIII FIG Congress, October 2006, Munich, Germany.

Revised August 2019 